\title{
ANALISIS JALUR UNTUK PENGARUH ANGKA HARAPAN HIDUP, HARAPAN LAMA SEKOLAH, RATA-RATA LAMA SEKOLAH TERHADAP INDEKS PEMBANGUNAN MANUSIA MELALUI PENGELUARAN RIIL PER KAPITA DI PROVINSI NUSA TENGGARA TIMUR
}

\author{
Oleh : \\ Irvana Arofah $^{1)}$ dan Siti Rohimah ${ }^{2)}$ \\ ${ }^{1)}$ Dosen Program Studi Matematika, Universitas Pamulang \\ ${ }^{2)}$ Mahasiswa Program Studi Matematika, Universitas Pamulang
}

\begin{abstract}
ABSTRAK
Indeks Pembangunan Manusia (IPM) merupakan suatu ukuran kondisi sumber daya manusia pada suatu negara. Indeks Pembangunan Manusia mempunyai tiga unsur yaitu kesehatan, pendidikan yang dicapai, dan standar kehidupan atau sering disebut ekonomi. Tujuan penelitian ini untuk mengetahui faktor-faktor Angka Harapan Hidup, Harapan Lama Sekolah,Rata-Rata Lama Sekolah, Terhadap Indeks Pembangunan Manusia (IPM) Melalui Pengeluaran Riil Per Kapita Di Provinsi Nusa Tenggara Timur. Dalam penelitian ini digunakan analisis jalur dengan menggunakan software SPSS. Analisis jalur mempunyai beberapa tahapan, yaitu Merumuskan hipotesis dan persamaan struktural, Menghitung koefisien jalur secara simultan (keseluruhan) dan secara individual, Menguji kesesuaian antar model analisis jalur, Memaknai dan menyimpulkan. Berdasarkan hasil penelitian menunjukkan bahwa besarnya kontribusi Angka Harapan Hidup $\left(X_{1}\right)$ terhadap Indeks Pembangunan Manusia $(Z)$ sebesar 0,095 . Besarnya kontribusi Harapan Lama Sekolah $\left(X_{2}\right)$ terhadap Indeks Pembangunan Manusia $(Z)$ sebesar 0,187. Besarnya kontribusi Rata-rata Lama Sekolah $\left(X_{3}\right)$ Indeks Pembangunan Manusia $(Z)$ sebesar 0,280 . Besarnya kontribusi Pengeluaran Riil PerKapita $(Y)$ terhadap Indeks Pembangunan Manusia $(Z)$ sebesar 0,571. Besarnya kontribusi secara simultan antara Harapan Hidup $\left(X_{1}\right)$, Harapan Lama Sekolah $\left(X_{2}\right)$, Rata-rata Lama Sekolah $\left(X_{3}\right)$, Pengeluaran Riil PerKapita $(Y)$ terhadap Indeks Pembangunan Manusia $(Z)$ sebesar 0,947 .
\end{abstract}

Kata kunci : Analisis Jalur (Path Analysis), Indeks Pembangunan Manusia, Angka Harapan Hidup, Harapan Lama Sekolah, Rata-Rata Lama Sekolah

\begin{abstract}
The Human Development Index (HDI) is a measure of the condition of human resources in a country. Human Development Index has three elements, namely health, education achieved, and standard of living or often called the economy. The purpose of this study was to determine the factors of Life Expectancy, Expectation of School Duration, Average Length of School, Against the Human Development Index (HDI) Through Real Expenditure Per Capita in East Nusa Tenggara Province. In this study, path analysis was used by using SPSS software. Path analysis has several stages, namely formulating hypotheses and structural equations, calculating path coefficients
\end{abstract}


simultaneously (whole) and individually, testing the suitability between path analysis models, interpreting and concluding. Based on the results of the study indicate that the contribution of Life Expectancy to the Human Development Index is 0.095. The magnitude of the contribution of School Expectations to the Human Development Index is 0.187. The magnitude of the contribution of the Average School Length of the Human Development Index is 0.280 . The amount of the contribution of Real Expenditures for PerKapita to the Human Development Index is 0.571. The magnitude of the contribution simultaneously between Life Expectancy, School Duration Expectation, Average Length of School, Real Expenditure of PerKapita on Human Development Index is 0.947 .

Keywords: Path Analysis, Human Development Index, Life Expectancy, School Length Expectation, Average School Duration

\section{PENDAHULUAN}

Manusia adalah kekayaan bangsa yang sesungguhnya dan modal dasar pembangunan. Tujuan utama pembangunan adalah menciptakan lingkungan yang memungkinkan rakyat menikmati umur panjang, sehat, dan menjalankan kehidupan yang produktif. Hal ini nampaknya sederhana. Tetapi seringkali terlupakan oleh kesibukan jangka pendek untuk mengumpulkan harta dan uang. (UNDP: Humant Development Report, 2000: 16).

Indeks Pembangunan Manusia mempunyai tiga unsur yaitu kesehatan, pendidikan yang dicapai, dan standar kehidupan atau sering disebut ekonomi. Jadi ketiga unsur ini sangat penting dalam menentukan tingkat kemampuan suatu provinsi untuk meningkatkan IPMnya. Ketiga unsur tersebut tidak berdiri sendiri, melainkan saling memengaruhi satu sama yang lainnya. Selain itu juga dipengaruhi oleh faktor-faktor lain, seperti ketersediaan kesempatan kerja, yang pada gilirannya ditentukan oleh pertumbuhan ekonomi, infrastruktur dan kebijakan pemerintah. Jadi IPM di suatu daerah akan meningkat apabila ketiga unsur tersebut dapat ditingkatkan, nilai IPM yang tinggi menandakan keberhasilan pembangunan ekonomi di daerah tersebut.

Kualitas pembangunan manusia menjadi hal yang sangat penting dalam strategi kebijakan nasional untuk pembangunan ekonomi. Penekanan terhadap pentingnya kualitas pembangunan manusia menjadi suatu kebutuhan karena dengan sumber daya yang unggul akan menghasilkan seluruh tatanan kehidupan yang maju diberbagai bidang baik sosial, ekonomi, lingkungan, sehingga kualitas manusia memiliki andil besar dalam menentukan keberhasilan pengolahan pembangunan wilayahnya.

Untuk mengukur kualitas pembangunan manusia dapat dilihat dari capaian angka IPM. Jadi setiap provinsi di Indonesia yang memiliki angka IPM yang mendekati angka 100 maka pembangunan manusia yang ada di daerah tersebut semakin baik, sedangkan daerah yang memiliki angka IPM yang mendekati nol maka daerah tersebut memiliki pembangunan manusia yang buruk. Adapun kategori dalam menentukan tinggi atau rendahnya IPM suatu daerah, yaitu : Sangat Tinggi : IPM $\geq 80$, Tinggi : $70 \leq \mathrm{IPM}<80$, Sedang : $60 \leq \mathrm{IPM}<70$, Rendah : IPM $<$ 60 (BPS-Bappeda-UNDP, 2015).

Berdasarkan latar belakang diatas penulis termotivasi untuk melakukan penelitian yang berjudul "Analisis Jalur Untuk Pengaruh Angka Harapan Hidup, Harapan Lama Sekolah,Rata- 
Rata Lama Sekolah, Terhadap Indeks Pembangunan Manusia (IPM) Melalui Pengeluaran Riil Per Kapita Di Provinsi Nusa Tenggara Timur".

Berdasarkan latar belakang tersebut diatas, maka perumusan masalah dalam penelitian ini adalah sebagai berikut :

1) Seberapa besar pengaruh hubungan kausal antara angka harapan hidup $\left(X_{1}\right)$ terhadap pengeluaran riil per kapita $(\mathrm{Y})$ ?

2) Seberapa besar pengaruh hubungan kausal antara harapan lama sekolah $\left(X_{2}\right)$ terhadap pengeluaran riil per kapita $(\mathrm{Y})$ ?

3) Seberapa besar pengaruh hubungan kausal antara rata-rata lama sekolah $\left(X_{3}\right)$ terhadap pengeluaran riil per kapita (Y) ?

4) Seberapa besar pengaruh hubungan kausal antara angka harapan hidup $\left(X_{1}\right)$, harapan lama sekolah $\left(\mathrm{X}_{2}\right)$, dan rata-rata lama sekolah $\left(\mathrm{X}_{3}\right)$ secara bersama-sama terhadap pengeluaran riil per kapita $(\mathrm{Y})$ ?

5) Seberapa besar pengaruh hubungan kausal antara angka harapan hidup $\left(X_{1}\right)$ terhadap indeks pembangunan manusia $(\mathrm{Z})$ ?

6) Seberapa besar pengaruh hubungan kausal antara harapan lama sekolah $\left(X_{2}\right)$ terhadap indeks pembangunan manusia $(\mathrm{Z})$ ?

7) Seberapa besar pengaruh hubungan kausal antara rata-rata lama sekolah $\left(X_{3}\right)$ terhadap indeks pembangunan manusia $(\mathrm{Z})$ ?

8) Seberapa besar pengaruh hubungan kausal antara pengeluaran riil per kapita (Y) terhadap indeks pembangunan manusia $(\mathrm{Z})$ ?

9) Seberapa besar pengaruh hubungan kausal antara angka harapan hidup $\left(X_{1}\right)$, harapan lama sekolah $\left(\mathrm{X}_{2}\right)$, rata-rata lama sekolah $\left(\mathrm{X}_{3}\right)$, dan pengeluaran riil per kapita $(\mathrm{Y})$ secara bersama-sama terhadap indeks pembangunan manusia $(\mathrm{Z})$ ?

10) Seberapa besar pengaruh hubungan kausal angka harapan hidup $\left(X_{1}\right)$ melalui pengeluaran riil per kapita (Y) terhadap indeks pembangunan manusia (Z) ?

11) Seberapa besar pengaruh hubungan kausal harapan lama sekolah $\left(X_{2}\right)$ melalui pengeluaran riil per kapita $(\mathrm{Y})$ terhadap indeks pembangunan manusia $(\mathrm{Z})$ ?

12) Seberapa besar pengaruh hubungan kausal rata-rata lama sekolah $\left(X_{3}\right)$ melalui pengeluaran riil per kapita $(\mathrm{Y})$ terhadap indeks pembangunan manusia $(\mathrm{Z})$ ?

13) Seberapa besar hubungan angka harapan hidup $\left(X_{1}\right)$ terhadap harapan lama sekolah $\left(X_{2}\right)$ ?

14) Seberapa besar hubungan angka harapan hidup $\left(X_{1}\right)$ terhadap rata-rata lama sekolah $\left(X_{3}\right)$ ?

15) Seberapa besar hubungan harapan lama sekolah $\left(X_{2}\right)$ terhadap rata-rata lama sekolah $\left(X_{3}\right)$ ?

Batasan masalah diperlukan agar penelitian lebih optimal, adapun batasan masalah pada penelitian ini adalah sebagai berikut :

1) Menggunakan metode analisis deskripsi dan analisis jalur.

2) Faktor-faktor yang digunakan adalah angka harapan hidup, harapan lama sekolah dan ratarata lama sekolah serta pengeluaran riil per kapita yang disesuaikan terhadap indeks pembangunan manusia.

3) Unit data yang digunakan 21 Kabupaten dan 1 Kotamadya di Provinsi Nusa Tenggara Timur.

4) Diambil dari tahun 2012 sampai dengan 2016. 


\section{TINJAUAN PUSTAKA}

Menurut BPS, pemikiran tentang pembangunan telah mengalami pergeseran, yaitu dari pembangunan yang berorientasi pada produksi (production centered development) pada dekade 60-an ke paradigma pembangunan yang lebih menekankan pada distribusi hasil-hasil pembangunan (distribution growth development) selama dekade 70-an. Selanjutnya pada dekade 80-an, muncul paradigma pembangunan yang berorientasi pada pemenuhan kebutuhan dasar masyarakat (basic need development), dan akhirnya menuju paradigma pembangunan yang terpusat pada manusia (human centered development) yang muncul pada tahun 1990-an.

Ada enam alasan mengapa paradigma pembangunan manusia ini bernilai penting, yaitu: (1) Pembangunan bertujuan akhir meningkatkan harkat dan martabat manusia; (2) Mengemban misi pemberantasan kemiskinan; (3) Mendorong peningkatan produktivitas secara maksimal dan meningkatkan kontrol atas barang dan jasa; (4) Memelihara konservasi alam (lingkungan) dan menjaga keseimbangan ekosistem; (5) Memperkuat basis civil society dan institusi politik guna mengembangkan demokrasi; dan (6) Merawat stabilitas sosial politik yang kondusif bagi implementasi pembangunan (Basu dalam Pambudi, 2008).

Menurut UNDP dalam BPS 2008, pembangunan manusia adalah suatu proses untuk memperbesar pilihan-pilihan bagi manusia (a process of enlarging people's choices). Dari definisi ini dapat ditarik kesimpulan bahwa fokus pembangunan suatu negara adalah penduduk, karena penduduk adalah kekayaan nyata suatu negara. Konsep atau definisi pembangunan manusia tersebut pada dasarnya mencakup dimensi pembangunan yang sangat luas. Definisi ini lebih luas dari definisi pembangunan yang hanya menekankan pada pertumbuhan ekonomi. Dalam konsep pembangunan manusia, pembangunan seharusnya dianalisis serta dipahami dari sudut manusianya, bukan hanya dari pertumbuhan ekonominya.

Pembangunan harus mengutamakan penduduk sebagai pusat perhatian dan pembangunan dimaksudkan untuk memperbesar pilihan-pilihan bagi penduduk, tidak hanya untuk meningkatkan pendapatan mereka. Oleh karena itu, konsep pembangunan manusia harus terpusat pada penduduk secara keseluruhan, dan bukan hanya pada aspek ekonomi saja. Pembangunan manusia memperhatikan bukan hanya pada upaya meningkatkan kemampuan (capability) manusia tetapi juga pada upayaupaya memanfaatkan kemampuan manusia tersebut secara optimal. Pembangunan manusia menjadi dasar penentuan tujuan pembangunan dan dalam menganalisis pilihan-pilihan untuk mencapainya.

\section{Perbandingan Komponen Indeks Pembangunan Manusia}

Alasan yang dijadikan perubahan metodologi penghitungan IPM yaitu :

1. Beberapa indikator sudah tidak tepat untuk digunakan dalam penghitungan IPM. Angka melek huruf sudah tidak relevan dalam mengukur pendidikan secara utuh karena tidak dapat menggambarkan kualitas pendidikan. Selain itu, karena angka melek huruf di sebagian besar daerah sudah tinggi, sehingga tidak dapat membedakan tingkat pendidikan antardaerah dengan baik. PDB per kapita tidak dapat menggambarkan pendapatan masyarakat pada suatu wilayah.

2. Penggunaan rumus rata-rata aritmatik dalam penghitungan Indeks Pembangunan Manusia menggambarkan bahwa capaian yang rendah di suatu dimensi dapat ditutupi oleh capaian tinggi dari dimensi lain. 
Tabel 2.1 Perbandingan IPM metode lama dan metode baru

\begin{tabular}{|c|c|c|c|c|}
\hline \multirow{2}{*}{ Dimensi } & \multicolumn{2}{|c|}{ Metode Lama } & \multicolumn{2}{|c|}{ Metode Baru } \\
\hline & UNDP & BPS & UNDP & BPS \\
\hline 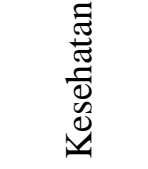 & $\begin{array}{l}\text { Angka Harapan } \\
\text { Hidup saat Lahir } \\
\text { (AHH) }\end{array}$ & $\begin{array}{l}\text { Angka Harapan } \\
\text { Hidup saat Lahir } \\
\text { (AHH) }\end{array}$ & $\begin{array}{c}\text { Angka Harapan } \\
\text { Hidup saat Lahir } \\
\text { (AHH) }\end{array}$ & $\begin{array}{c}\text { Angka Harapan } \\
\text { Hidup saat } \\
\text { Lahir (AHH) }\end{array}$ \\
\hline$\stackrel{\Xi}{\Xi}$ & $\begin{array}{c}\text { Angka Melek Huruf } \\
(\mathrm{AMH})\end{array}$ & $\begin{array}{c}\text { Angka Melek Huruf } \\
(\mathrm{AMH})\end{array}$ & $\begin{array}{l}\text { Harapan Lama } \\
\text { Sekolah (HLS) }\end{array}$ & $\begin{array}{l}\text { Harapan Lama } \\
\text { Sekolah (HLS) }\end{array}$ \\
\hline $\begin{array}{l}\frac{\pi}{0} \\
00 \\
0 \\
0 \\
0\end{array}$ & $\begin{array}{c}\text { Kombinasi Angka } \\
\text { Partisipasi Kasar } \\
\text { (APK) }\end{array}$ & $\begin{array}{l}\text { Rata-rata Lama } \\
\text { Sekolah } \\
\text { (RLS) }\end{array}$ & $\begin{array}{l}\text { Rata-rata Lama } \\
\text { Sekolah } \\
\text { (RLS) }\end{array}$ & $\begin{array}{c}\text { Rata-rata Lama } \\
\text { Sekolah } \\
\text { (RLS) }\end{array}$ \\
\hline 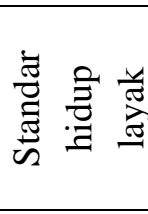 & $\begin{array}{l}\text { PDB per kapita } \\
\text { (PPP US\$) }\end{array}$ & $\begin{array}{c}\text { Pengeluaran } \\
\text { per kapita } \\
\text { Disesuaikan (Rp) }\end{array}$ & $\begin{array}{l}\text { PNB per kapita } \\
\text { (PPP US\$) }\end{array}$ & $\begin{array}{l}\text { Pengeluaran } \\
\text { per kapita } \\
\text { Disesuaikan } \\
(\mathrm{Rp})\end{array}$ \\
\hline 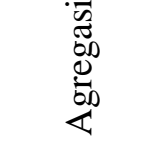 & \multicolumn{2}{|c|}{ Rata-rata Aritmatik } & \multicolumn{2}{|c|}{ Rata-rata Geometrik } \\
\hline
\end{tabular}

Dari penjelasan tersebut dapat disimpulkan bahwa komponen-komponen yang mempengaruhi IPM antara lain:

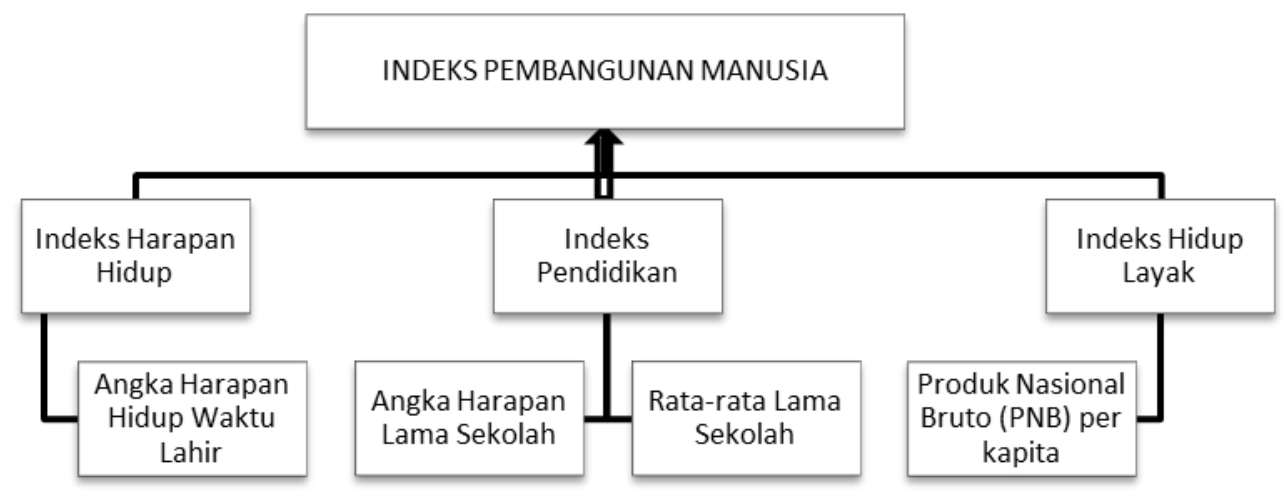

1. Indeks Harapan Hidup

\section{Gambar 2.9 Komponen IPM}

Indeks harapan hidup menunjukkan jumlah tahun hidup yang diharapkan dapat dinikmati penduduk suatu wilayah. Angka Harapan Hidup saat Lahir (AHH) perkiraan jumlah tahun hidup yang dapat ditempuh oleh seseorang sejak lahir yang berdiam di suatu wilayah dari sekelompok makhluk hidup tertentu. Harapan Hidup merupakan jumlah ratarata usia yang diperkirakan pada seseorang atas dasar angka kematian pada masa tersebut yang cenderung tidak berubah di masa mendatang.

Harapan hidup saat lahir adalah rata-rata usia yang dapat dicapai bayi tersebut dalam kondisi saat itu. Karena di negara berkembang banyak kematian terjadi selama masa bayi dan kanak-kanak, maka rata-rata harapan hidupnya jauh lebih rendah daripada di negara maju. 
Rata-rata tahun hidup yang masih akan dijalani oleh seseorang yang telah berhasil mencapai umur x, pada suatu tahun tertentu, dalam situasi mortalitas (Mortalitas adalah ukuran jumlah kematian (umumnya, atau karena akibat yang spesifik) pada suatu populasi skala besar suatu populasi, per dikali satuan) yang berlaku di lingkngan masyarakatnya. Mortalitas khusus mengekspresikan pada jumlah satuan kematian per 1000 individu per tahun, hingga, rata-rata mortalitas sebesar 9.5 berarti pada populasi 100.000 terdapat 950 kematian per tahun.

Rumusan yang digunakan idealnya angka harapan hidup dihitung berdasarkan angka kematian menurut umur (age specific death rate/ASDR) yang datanya diperoleh dari catatan registrasi kematian secara bertahun-tahun sehingga dimungkinkan dibuat tabel kematian.

Kegunaan Angka Harapan Hidup merupakan alat untuk mengevaluasi kinerja pemerintah dalam meningkatkan kesejahteraan penduduk pada umumnya, dan meningkatkan derajat kesehatan pada khususnya. Angka Harapan Hidup yang rendah di suatu daerah harus diikuti dengan program pembangunan kesehatan, dan program sosial lainnya termasuk kesehatan lingkungan, kecukupan gizi dan kalori termasuk program pemberantasan kemiskinan.

2. Indeks Hidup Layak

Untuk mengukur dimensi standar hidup layak (daya beli), UNDP menggunakan indikator yang dikenal dengan real per kapita GDP adjusted. Untuk perhitungan IPM sub nasional (provinsi atau kabupaten/kota) tidak memakai PDRB per kapita karena PDRB per kapita hanya mengukur produksi suatu wilayah dan tidak mencerminkan daya beli riil masyarakat yang merupakan konsentrasi IPM. Sedangkan BPS dalam menghitung standar hidup layak menggunakan rata-rata pengeluaran per kapita riil yang disesuaikan (daya beli) dengan formula Atkinson.

Pengertian daya beli masyarakat menurut Dr. Supawi pawengan adalah kemampuan masyarakat sebagai konsumen untuk membeli barang atau jasa yang dibutuhkan. Daya beli masyarakat ini ditandai dengan meningkat ataupun menurun, dimana daya beli meningkat jika lebih tinggi dibanding periode lalu sedangkan daya beli menurun ditandai dengan lebih tingginya kemampuan beli masyarakat dari pada periode sebelumnya. Penghitungan Paritas Daya Beli. Dihitung dari bundel komoditas makanan dan non makanan. Kegunaannya adalah menggambarkan tingkat kesejahteraan yang dinikmati oleh penduduk sebagai dampak semakin membaiknya ekonomi.

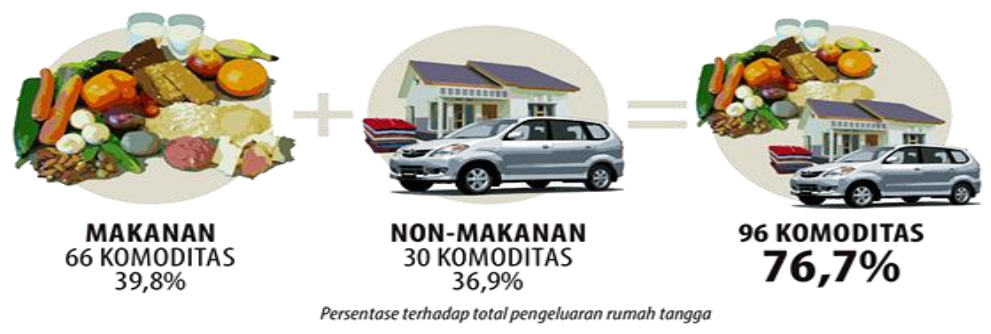

Gambar 2.10 Persentase Daya Beli

3. Indeks Pendidikan

Penghitungan Indeks Pendidikan (IP) mencakup dua indikator yaitu Angka Harapan Lama Sekolah (HLS) didefinisikan sebagai lamanya sekolah (dalam tahun) yang diharapkan akan dirasakan oleh anak pada umur tertentu di masa mendatang. Diasumsikan bahwa peluang anak tersebut akan tetap bersekolah pada umur-umur berikutnya sama 
dengan peluang penduduk yang bersekolah per jumlah penduduk untuk umur yang sama saat ini.

Angka Harapan Lama Sekolah dihitung untuk penduduk berusia 7 tahun ke atas. HLS dapat digunakan untuk mengetahui kondisi pembangunan sistem pendidikan di berbagai jenjang yang ditunjukkan dalam bentuk lamanya pendidikan (dalam tahun) yang diharapkan dapat dicapai oleh setiap anak. Contohnya Harapan Lama Sekolah Kota Kupang pada tahun 2015 adalah sebesar 15,75 tahun. Artinya bahwa lamanya sekolah yang diharapkan akan dirasakan oleh anak pada umur tertentu (7 tahun ke atas) di masa mendatang adalah selama 15,75 tahun atau setara dengan mengenyam pendidikan sampai dengan kuliah semester VI. HLS dapat digunakan untuk mengetahui kondisi pembangunan sistem pendidikan di berbagai jenjang yang ditunjukkan dalam bentuk lamanya pendidikan (dalam tahun) yang diharapkan dapat dicapai oleh setiap anak.

Rata-rata Lama Sekolah (RLS) didefinisikan sebagai jumlah tahun yang digunakan oleh penduduk dalam menjalani pendidikan formal. Cakupan penduduk yang dihitung Rata-rata lama sekolah adalah penduduk berusia 25 tahun ke atas. Contohnya Rata-rata Lama Sekolah Kota Kupang pada tahun 2015 adalah sebesar 11.43 tahun. Artinya bahwa rata-rata tingkat pendidikan penduduk usia sekolah (7 tahun atau lebih) di Kota Kupang dapat menyelesaikan sekolah hanya sampai kelas 2 Sekolah Menengah Atas (SMA). Jumlah tahun belajar penduduk usia 15 tahun ke atas yang telah diselesaikan dalam pendidikan formal (tidak termasuk tahun yang mengulang).

Untuk menghitung Rata-rata Lama Sekolah dibutuhkan informasi: a. Partsipasi sekolah b. Jenjang dan jenis pendidikan yang pernah/sedang diduduki c. Ijasah tertinggi yang dimiliki d. Tingkat/kelas tertinggi yang pernah/sedang diduduki. Tingginya angka Rata-rata Lama Sekolah (mean years of schooling) menunjukkan jenjang pendidikan yang pernah/sedang diduduki oleh seseorang. Semakin tinggi angka MYS maka semakin lama/tinggi jenjang pendidikan yang ditamatkannya.

\section{BAB III. METODOLOGI PENELITIAN}

\section{Data Dan Sumbernya}

Metode pengumpulan data pada penelitian ini dengan mengunduh data kuantitatif berupa data sekunder yang didapatkan dari badan pusat statistik pada kurun waktu 2012-2016. Jenis data yang diperlukan seperti ditujukan pada tabel berikut.

Tabel 3.1 Sumber Data

\begin{tabular}{|l|c|l|}
\hline \multicolumn{1}{|c|}{ Jenis Data } & Tahun & \multicolumn{1}{c|}{ Sumber } \\
\hline Angka Harapan Hidup & $2012-2016$ & Badan Pusat Statistik \\
\hline Angka Harapan Lama Sekolah & $2012-2016$ & Badan Pusat Statistik \\
\hline Rata-Rata Lama Sekolah & $2012-2016$ & Badan Pusat Statistik \\
\hline $\begin{array}{l}\text { Pengeluaran Rill Per Kapita Yang } \\
\text { Disesuaikan }\end{array}$ & $2012-2016$ & Badan Pusat Statistik \\
\hline Indeks Pembangunan Manusia & $2012-2016$ & Badan Pusat Statistik \\
\hline
\end{tabular}

Unit data adalah seluruh Kabupaten/Kota di Provinsi Nusa Tenggara Timur yang terdiri dari 21 Kabupaten dan 1 Kotamadya.

\section{Variabel Penelitian}

Dalam penelitian ini terdapat 5 variabel yang akan diteliti yaitu tiga variabel eksogen dan dua variabel endogen.

1. Variabel eksogen (X) 
Adalah variabel yang mempengaruhi variabel endogen yaitu :

a. Angka Harapan Hidup $\left(\mathrm{X}_{1}\right)$

b. Rata-Rata Lama Sekolah $\left(\mathrm{X}_{3}\right)$

c. Harapan Lama Sekolah $\left(\mathrm{X}_{2}\right)$

2. Variabel intervening

Adalah variabel penyela yang terletak diantara variabel dependen dan variabel independen (sugiyono, 2007). Tujuan dari variabel intervening ini adalah untuk menguji pengaruh langsung dan pengaruh tidak langsung antara variabel independen terhadap variabel dependen, yaitu :

a. Variabel eksogen (Y) adalah variabel yang mempengaruhi endogen (Z)

b. Variabel endogen $(\mathrm{Y})$ adalah variabel yang dipengaruhi variabel eksogen $(\mathrm{X})$

3. Variabel endogen $(\mathrm{Y})$ dan $(\mathrm{Z})$

Adalah variabel yang dipengaruhi variabel eksogen yaitu :

a. Pengeluaran Rill Per Kapita (Y)

b. Indeks Pembangunan Manusia (Z)

\section{Metode Analisis}

Metode yang digunakan pada penelitian ini yaitu analisis deskriptif dan analisis jalur. Analisis deskriptif pada penelitian ini digunakan untuk melihat dinamika angka harapan hidup, rata-rata lama sekolah, pengeluaran rill perkapita yang disesuaikan dan indeks pembangunan manusia (IPM).

Tahapan Analisis Jalur:

1) Merumuskan hipotesis dan persamaan struktural.

Misal : $\mathrm{Y}=\rho_{y x 1} \mathrm{X}_{1}+\rho_{y \times 2} \mathrm{X}_{2}+\rho_{y x 3} \mathrm{X}_{3}+\rho_{y} \varepsilon_{1}$

2) Menghitung koefisien jalur yang didasarkan pada koefisien regresi.

a. Menggambarkan diagram jalur lengkap, tentukan sub-sub strukturnya dan merumuskan persamaan strukturnya yang sesuai dengan hipotesis yang diajukan.

b. Menghitung koefisien regresi untuk struktur yang telah dirumuskan.

Pada dasarnya koefisien jalur adalah koefisien regresi yang distandarkan yaitu koefisien regresi yang dihitung dari basis data yang telah diset dalam angka baku atau Z-score. Koefisien jalur yang distandarkan ini digunakan untuk menjelaskan besarnya pengaruh (bukan memprediksi) variabel bebas (eksogen) terhadap variabel lain yang diberlakukan sebagai variabel terikat (endogen).

3) Menghitung koefisien jalur secara simultan (keseluruhan).

Uji secara keseluruhan hipotesisi statistik dirumuskan sebagai berikut :

$\mathrm{H}_{0}: \rho_{y x 1}=\rho_{y x 2}=\ldots \ldots \ldots \ldots=\rho_{y x_{k}}=0$

$\mathrm{H}_{\mathrm{a}}: \rho_{y x 1}=\rho_{y x 2}=\ldots \ldots \ldots \ldots=\rho_{y x_{k}} \neq 0$

a. Kaidah pengujian signifikansi secara manual : menggunakan tabel $\mathrm{F}$.

$$
F=\frac{(n-k-1) R_{y x_{k}}^{2}}{k\left(1-R_{y x_{k}}^{2}\right)}
$$

Keterangan :

$\mathrm{n} \quad=$ jumlah sampel

$\mathrm{k} \quad=$ jumlah variabel eksogen

$R_{y x_{k}}^{2}=R_{\text {Square }}$ 
Jika $F_{\text {hitung }} \geq F_{\text {tabel }}$, maka tolak $\mathrm{H}_{0}$ artinya signifikan dan

Jika $F_{\text {hitung }} \leq F_{\text {tabel }}$, maka terima $\mathrm{H}_{0}$ artinya tidak signifikan dan

Dengan taraf signifikan $(\alpha)=0,05$

b. Kaidah pengujian signifikansi :

- Jika angka signifikan (sig) $\leq 0,05$ maka $\mathrm{H}_{0}$ ditolak dan $\mathrm{H}_{\mathrm{a}}$ diterima, artinya signifikan.

- Jika angka signifikan (sig) $\geq 0,05$ maka $\mathrm{H}_{0}$ diterima dan $\mathrm{H}_{\mathrm{a}}$ ditolak, artinya tidak signifikan.

4) Menghitung koefisien jalur secara individual.

Hipotesis penelitian yang akan diuji dirumuskan menjadi hipotesis statistic berikut :

$\mathrm{H}_{0}: \rho_{y x_{1}}=0$

$\mathrm{H}_{\mathrm{a}}: \rho_{y x_{1}}>0$

Secara individual uji statistik yang digunakan adalah dengan menggunakan uji $\mathrm{T}$. $t_{k}=\frac{\rho_{k}}{s e_{\rho k}} ;(d k=n-k-1)$

Statistik $s e_{\rho x 1}$ diperoleh dari hasil komputasi pada SPSS untuk analisis regresi setelah data ordinal ditransformasi ke interval.

Selanjutnya untuk mengetahui signifikansi analisis jalur bandingkan antara nilai probabilitas 0,05 dengan nilai probabilitas Sig dengan dasar pengambilan keputusan sebagai berikut :

- Jika angka signifikan (sig) $\leq 0,05$ maka $\mathrm{H}_{0}$ ditolak dan $\mathrm{H}_{\mathrm{a}}$ diterima, artinya signifikan.

- Jika angka signifikan (sig) $\geq 0,05$ maka $\mathrm{H}_{0}$ diterima dan $\mathrm{H}_{\mathrm{a}}$ ditolak, artinya tidak signifikan.

5) Menguji kesesuaian antar model analisis jalur.

Uji kesesuaian model dimaksudkan untuk menguji apakah model yang diusulkan memiliki kesesuaian (fit) dengan data atau tidak. Shumacker 7 Lomax (1996:43) dan Kusnaedi, (2005:19) mengatakan bahwa analisis jalur untuk suatu model yang diusulkan dikatakan fit dengan data apabila matrik kolerasi sampel tidak jauh berbeda dengan matrik korelasi estimasi (reproduced correlation matrix) atau korelasi yang diharapkan (expected colleration matrix).

6) Merangkum kedalam tabel

7) Memaknai dan menyimpulkan

\section{HASIL DAN PEMBAHASAN}

\section{Hasil Penelitian}

Berdasarkan perhitungan analisis jalur struktur tersebut, maka penulis akan memberikan informasi secara objektif sebagai berikut:

\section{Hasil kontribusi sub-struktur 1}

1) Kontribusi Angka Harapan Hidup $\left(X_{1}\right)$ secara langsung yang tidak mempengaruhi Pengeluaran Riil Per Kapita (Y) sebesar $0,047^{2}=0,002$ atau $0,2 \%$.

2) Kontribusi Harapan Lama Sekolah $\left(X_{2}\right)$ yang secara langsung mempengaruhi Pengeluaran Riil Per Kapita (Y) sebesar $0,182^{2}=0,033$ atau 3,3\%. 
3) Kontribusi Rata-rata Lama Sekolah $\left(\mathrm{X}_{3}\right)$ yang secara langsung mempengaruhi Pengeluaran Riil Per Kapita (Y) sebesar 0,714 $=0,5098$ atau 50,98\%.

4) Kontribusi Angka Harapan Hidup $\left(X_{1}\right)$, Harapan Lama Sekolah $\left(X_{2}\right)$, Rata-rata Lama Sekolah $\left(\mathrm{X}_{3}\right)$ secara simultan yang langsung mempengaruhi Pengeluaran Riil Per Kapita (Y) adalah $R_{\text {square }}=0,698$ atau $69,8 \%$. Indeks errornya sebesar 0,302 atau 30,2\% yang dipengaruhi oleh variabel lain.

\section{Hasil kontribusi sub-struktur 2}

1) Kontribusi Angka Harapan Hidup $\left(X_{1}\right)$ yang secara langsung mempengaruhi Indeks Pembangunan Manusia (Z) sebesar $0,095^{2}=0,009$ atau 0,9\%

2) Kontribusi Harapan Lama Sekolah $\left(X_{2}\right)$ yang secara langsung mempengaruhi Indeks Pembangunan Manusia $(Z)$ sebesar $0,187^{2}=0,035$ atau 3,5\%

3) Kontribusi Rata-rata Lama Sekolah $\left(X_{3}\right)$ yang secara langsung mempengaruhi Indeks Pembangunan Manusia $(\mathrm{Z})$ sebesar $0,280^{2}=0,078$ atau $7,8 \%$

4) Kontribusi Pengeluaran Riil Per Kapita (Y) yang secara langsung mempengaruhi Indeks Pembangunan Manusia $(Z)$ sebesar $0,571^{2}=0,326$ atau $32,6 \%$

5) Kontribusi Angka Harapan Hidup ( $\left.X_{1}\right)$, Harapan Lama Sekolah $\left(X_{2}\right)$, Rata-rata Lama Sekolah $\left(\mathrm{X}_{3}\right)$ dan Pengeluaran Riil Per Kapita (Y) secara simultan yang langsung mempengaruhi Indeks Pembangunan Manusia (Z) adalah $R_{\text {square }}=0,947$ atau 94,7\%. Indeks errornya sebesar 0,053 atau 5,3\% yang dipengaruhi oleh variabel lain.

\section{KESIMPULAN}

kesimpulan yang diambil untuk menjawab dari pertanyaan-pertanyaan pada rumusan masalah bahwa dari semua faktor-faktor yang diuji mempunyai pengaruh sebagai berikut :

1) Besarnya pengaruh angka harapan hidup $\left(X_{1}\right)$ secara langsung berkontribusi secara tidak signifikan terhadap pengeluaran riil per kapita $(\mathrm{Y})$ sebesar 0,047 .

2) Besarnya pengaruh harapan lama sekolah $\left(X_{2}\right)$ secara langsung berkontribusi secara signifikan terhadap pengeluaran riil per kapita (Y) sebesar 0,182 .

3) Besarnya pengaruh rata-rata lama sekolah $\left(\mathrm{X}_{3}\right)$ secara langsung berkontribusi secara signifikan terhadap pengeluaran riil per kapita $(\mathrm{Y})$ sebesar 0,714 .

4) Besarnya pengaruh angka harapan hidup $\left(X_{1}\right)$, harapan lama sekolah $\left(X_{2}\right)$, dan rata-rata lama sekolah $\left(\mathrm{X}_{3}\right)$ secara bersama-sama dan signifikan terhadap pengeluaran riil per kapita (Y) sebesar 0,698.

5) Besarnya pengaruh angka harapan hidup $\left(X_{1}\right)$ secara langsung berkontribusi secara signifikan terhadap indeks pembangunan manusia (Z) sebesar 0,095.

6) Besarnya pengaruh harapan lama sekolah $\left(\mathrm{X}_{2}\right)$ secara langsung berkontribusi secara signifikan terhadap indeks pembangunan manusia $(\mathrm{Z})$ sebesar 0,187 .

7) Besarnya pengaruh antara rata-rata lama sekolah $\left(X_{3}\right)$ secara langsung berkontribusi secara signifikan terhadap indeks pembangunan manusia (Z) sebesar 0,280 .

8) Besarnya pengaruh pengeluaran riil per kapita (Y) secara langsung berkontribusi secara signifikan terhadap indeks pembangunan manusia (Z) sebesar 0,571 . 
9) Besarnya pengaruh angka harapan hidup $\left(X_{1}\right)$, harapan lama sekolah $\left(X_{2}\right)$, rata-rata lama sekolah $\left(\mathrm{X}_{3}\right)$, dan pengeluaran riil per kapita $(\mathrm{Y})$ secara bersama-sama dan signifikan terhadap indeks pembangunan manusia (Z) sebesar 0,947.

10) Besarnya pengaruh angka harapan hidup $\left(X_{1}\right)$ melalui pengeluaran riil per kapita $(Y)$ berkontribusi secara simultan dan signifikan terhadap indeks pembangunan manusia $(\mathrm{Z})$ sebesar 0,027 .

11) Besarnya pengaruh harapan lama sekolah $\left(\mathrm{X}_{2}\right)$ melalui pengeluaran riil per kapita $(Y)$ berkontribusi secara simultan dan signifikan terhadap indeks pembangunan manusia $(\mathrm{Z})$ sebesar 0,104 .

12) Besarnya pengaruh rata-rata lama sekolah $\left(X_{3}\right)$ melalui pengeluaran riil per kapita $(Y)$ berkontribusi secara simultan dan signifikan terhadap indeks pembangunan manusia $(\mathrm{Z})$ sebesar 0,408 .

13) Besarnya hubungan angka harapan hidup $\left(X_{1}\right)$ terhadap harapan lama sekolah $\left(X_{2}\right)$ sebesar 0,058 berdasarkan hasil penelitian hubungan antara angka harapan hidup dan harapan lama sekolah sangat lemah dan tidak signifikan.

14) Besarnya hubungan angka harapan hidup $\left(X_{1}\right)$ terhadap rata-rata lama sekolah $\left(X_{3}\right)$ sebesar 0,294 berdasarkan hasil penelitian hubungan antara angka harapan hidup dan rata-rata lama sekolah cukup kuat dan signifikan.

15) Besarnya hubungan harapan lama sekolah $\left(X_{2}\right)$ terhadap rata-rata lama sekolah $\left(X_{3}\right)$ sebesar 0,591 berdasarkan hasil penelitian hubungan antara harapan lama sekolah dan ratarata lama sekolah kuat dan signifikan.

\section{DAFTAR PUSTAKA}

Al-Rasyid, H (1994). Analisis Jalur (Path Analysis) Sebagai Sarana Statistika Dalam Analisis Kausal. Bandung: Fakultas Ekonomi UNPAD.

Badan Pusat Statistik. 2013. Nusa Tenggara Timur Dalam Angka 2013. Jakarta : Badan Pusat Statistik.

Badan Pusat Statistik. 2014. Nusa Tenggara Timur Dalam Angka 2014. Jakarta : Badan Pusat Statistik.

Badan Pusat Statistik. 2015. Nusa Tenggara Timur Dalam Angka 2015. Jakarta : Badan Pusat Statistik.

Badan Pusat Statistik. 2016. Nusa Tenggara Timur Dalam Angka 2016. Jakarta : Badan Pusat Statistik.

Badan Pusat Statistik. 2017. Nusa Tenggara Timur Dalam Angka 2017. Jakarta : Badan Pusat Statistik.

Dewi Kacaribu, Rosinta. 2013. Analisis Indeks Pembangunan Manusia Dan Faktor-faktor Yang Memengaruhi Di Provinsi Papua. Skripsi. Institute Pertanian Bogor. Bogor.

Imam, Gunawan. 2016. Pengantar Statistik Inferensial. Jakarta : Penerbit PT. Raja Grafindo Persada.

Ilhami, Syahril. 2014. Analisis Pengaruh Anggaran Pendidikan Terhadap Indeks Pembangunan Manusia Di Indonesia. Tesis. Sekolah Pasca Sarjana. Institut Pertanian Bogor. Bogor.

Jhingan, M.L. (2003). Ekonomi Pembangunan dan Perencanaan. Raja Grafind Pustaka : Jakarta.

Narbuko, Cholidi, dan Abu Achmadi. 2013. Metodologi Penelitian. Penerbit Bumi Aksara. 
Riduwan, dan Engkos Achmad Kuncoro. 2012. Cara Menggunakan Dan Memaknai Path Analysis (Analisis Jalur). Bandung : Alfabeta

Sarwono, Jonathan. 2007. Analisis Jalur Untuk Riset Bisnis Dengan SPSS. Bandung : Penerbit Andi.

Santoso, Singgih. 2012. Aplikasi SPSS Pada Statistik Multivariat. Jakarta : Penerbit PT. Elex Media Kompatindo 